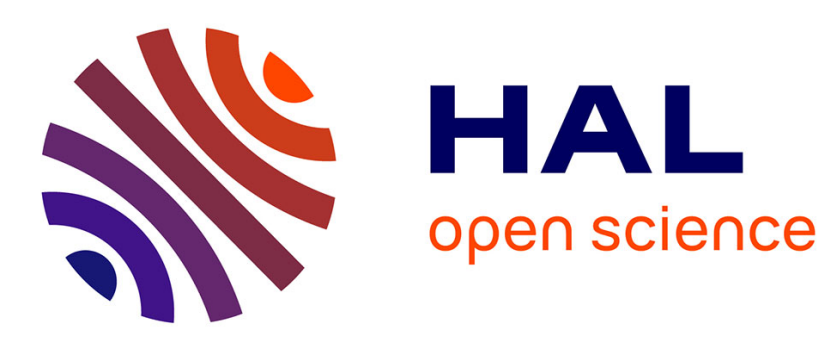

\title{
The Azodyn crop model as a decision support tool for choosing cultivars
}

\author{
Aude A. Barbottin, Marianne Le Bail, Marie-Helene M.-H. Jeuffroy
}

\section{To cite this version:}

Aude A. Barbottin, Marianne Le Bail, Marie-Helene M.-H. Jeuffroy. The Azodyn crop model as a decision support tool for choosing cultivars. Agronomy for Sustainable Development, 2006, 26 (2), pp.107-115. 10.1051/agro:2006003 . hal-02668578

\section{HAL Id: hal-02668578 \\ https://hal.inrae.fr/hal-02668578}

Submitted on 31 May 2020

HAL is a multi-disciplinary open access archive for the deposit and dissemination of scientific research documents, whether they are published or not. The documents may come from teaching and research institutions in France or abroad, or from public or private research centers.
L'archive ouverte pluridisciplinaire HAL, est destinée au dépôt et à la diffusion de documents scientifiques de niveau recherche, publiés ou non, émanant des établissements d'enseignement et de recherche français ou étrangers, des laboratoires publics ou privés.

$$
\text { Copyright }
$$




\title{
The Azodyn crop model as a decision support tool for choosing cultivars
}

\author{
A. BARBOTTIN ${ }^{a *}$, M. LE BAIL ${ }^{b}$, M.H. JEUfFrOYa \\ ${ }^{a}$ UMR Agronomie, INRA INA P-G, BP 01, 78850 Thiverval-Grignon, France \\ ${ }^{\mathrm{b}}$ UMR SAD-APT, INRA INA P-G, BP 01, 78850 Thiverval-Grignon, France
}

(Accepted 2 February 2006)

\begin{abstract}
We evaluated the Azodyn wheat crop model as a cultivar decision support tool using a set of 14 genotypes, tested in 21 contrasting environments. The results showed that the Azodyn crop model satisfactorily simulated yield and grain protein content for a large range of genotypes and environments, as shown by a root mean square error of $1.4 \mathrm{Mg} \mathrm{ha}^{-1}$ and $1.7 \mathrm{~g} 100 \mathrm{~g} \mathrm{MS}^{-1}$, respectively. The comparison between the observed and the simulated rankings of genotypes showed a ranking error of the model of one rank or less. The model was able to identify the best genotype to be used to obtain the highest yield in 20 cases out of 33 and the highest grain protein content in 48 cases out of 64 . As a new way to evaluate crop models as a decision support tool for cultivar choice, we compared the Azodyn predictive accuracy against the cultivar yield and grain protein average generally used by cultivar growers as a predictive model. We showed that in the main production conditions, the Azodyn predictions fit the yield and grain protein content observed better than the average.
\end{abstract}

crop model / cultivar / decision support tool / cultivar users / model evaluation

\section{INTRODUCTION}

Given the high genetic innovation rate with about 20 new cultivars are registered per year in the French winter wheat catalogue, it becomes time-consuming and expensive to test all new cultivars in all of the possible field conditions. Experiments used to support the choice of a cultivar are generally spread over large soil/climatic conditions with varied crop management, representing users' practices. Using these experiments, mean yield and grain protein content or ranking order between cultivars have been the most widely used statistics to compare and predict yield and grain protein content of genotypes over locations within a season, over the seasons at a given location or over location by season combinations (Feyerherm et al., 2004).

Because of time constraints, financial resources, and the large number of cultivars to be tested, these experiments are generally restricted to a small number of treatments in which the specific adaptations of the genotypes are not studied. Shorter et al. (1991) proposed the use of crop models as useful tools to help breeders to identify the best cultivar to use for various practices. In this way, models that were initially developed to understand crop growth have been increasingly modified (Boote et al., 2003; Colson et al., 1995) to help cultivar evaluation. Recently, some crop models have been proposed to evaluate a priori the effects of various phenotypic characters or gene combinations on yield, for a wide range of environmental conditions, to support breeding programs (Asseng et al., 2002a, 2003; Chapman et al., 2003; Hammer and Vanderlip, 1989). They have also been used as tools for cultivar management, identifying the best cultivar to be chosen, assuming the most probable environmental limiting factors (Agüera et al., 1997; Hammer and Muchow, 1994; Muchow et al., 1994). However, all the models mentioned above are mainly used in research, education, or for the overall design of cropping systems, generating information useful for system managers (Meinke et al., 1997; van Ittersum et al., 2003) rather than for crop management as described by Chatelin et al. (2005).

Using a model to support cultivar management supposes that the model be usable across a wide range of environmental conditions and does not require too many parameters and inputs. The model should also be able to answer the main questions asked by the growers, better than their own tools usually do. So well-tested simulation approaches may offer a time- and cost-effective alternative to experiments for cultivar evaluation and management. Nevertheless, this evaluation step is rarely performed (Welch et al., 2002).

The evaluation of crop models is traditionally performed through their predictive quality, by comparing observed versus simulated output data (Asseng et al., 2003; Brisson et al., 2003;

\footnotetext{
* Corresponding author: barbotti@grignon.inra.fr

Present address: UMR SAD-APT, INRA INA P-G, BP 01, 78850 Thiverval-Grignon, France.
} 
Table I. Experiments used for model validation: characteristics of each experimental site and mean weather data during the crop cycle (from sowing to the 1st August after harvest) (mean temperature: T, cumulative total radiation, and cumulative rainfall: CR).

\begin{tabular}{|c|c|c|c|c|c|c|c|c|c|}
\hline Location & Latitude, longitude & Year & Soil type & $\begin{array}{l}\text { Soil mineral N } \\
\text { at the end of winter } \\
\qquad\left(\mathrm{hg} \mathrm{ha}^{-1}\right)\end{array}$ & $\begin{array}{l}\text { Preceding } \\
\quad \text { crop }\end{array}$ & $\begin{array}{c}\text { Fertilizer } \mathrm{N} \text { applied } \\
\text { (low and high level) } \\
\qquad\left(\mathrm{kg} \mathrm{ha}^{-1}\right)\end{array}$ & $\begin{array}{c}\mathrm{T} \\
\left({ }^{\circ} \mathrm{C}\right)\end{array}$ & $\begin{array}{l}\text { Cumulative } \\
\text { total radiation } \\
\left(\mathrm{MJ} . \mathrm{m}^{-1}\right)\end{array}$ & $\begin{array}{c}\mathrm{CR} \\
(\mathrm{mm})\end{array}$ \\
\hline Clermont-Ferrand & $45^{\circ} 46^{\prime} \mathrm{N}, 03^{\circ} 05^{\prime} \mathrm{E}$ & 2001 & loamy-calcareous & 75 & Sunflower & $30-130$ & 11.40 & 3180 & 360 \\
\hline Clermont-Ferrand & $45^{\circ} 46^{\prime} \mathrm{N}, 03^{\circ} 05^{\prime} \mathrm{E}$ & 2002 & loamy-calcareous & 70 & Sunflower & $40-120$ & 10.09 & 3244 & 320 \\
\hline Dijon & $47^{\circ} 19^{\prime} \mathrm{N}, 05^{\circ} 01^{\prime} \mathrm{E}$ & 2001 & clay-loam & 41 & Vetch & $100-190$ & 10.57 & 3475 & 764 \\
\hline Le Moulon & $48^{\circ} 48^{\prime} \mathrm{N}, 02^{\circ} 08^{\prime} \mathrm{E}$ & 2001 & loam & 40 & Oat & $115-210$ & 10.5 & 2928 & 808 \\
\hline Le Moulon & $48^{\circ} 48^{\prime} \mathrm{N}, 02^{\circ} 08^{\prime} \mathrm{E}$ & 2002 & loam & 45 & Oat & $120-210$ & 10.3 & 3096 & 449 \\
\hline Lille & $50^{\circ} 39^{\prime} \mathrm{N}, 02^{\circ} 57^{\prime} \mathrm{E}$ & 2002 & clay-loam & 30 & Rapeseed & 180 & 9.7 & 2702 & 603 \\
\hline Mons & $49^{\circ} 56^{\prime} \mathrm{N}, 02^{\circ} 56^{\prime} \mathrm{E}$ & 2001 & loam & 55 & Rapeseed & $80-170$ & 9.8 & 3010 & 638 \\
\hline Rennes & $48^{\circ} 06^{\prime} \mathrm{N}, 01^{\circ} 47^{\prime} \mathrm{W}$ & 2001 & loamy-clay & 84 & Pea & $80-190$ & 11.47 & 3272 & 859 \\
\hline Rennes & $48^{\circ} 06^{\prime} \mathrm{N}, 01^{\circ} 47^{\prime} \mathrm{W}$ & 2002 & loamy-clay & 46 & Faba bean & $0-80$ & 10.77 & 3339 & 374 \\
\hline Toulouse & $43^{\circ} 31^{\prime} \mathrm{N}, 01^{\circ} 28^{\prime} \mathrm{E}$ & 2001 & loamy-calcareous & 80 & Pea & $52-165$ & 12.90 & 3782 & 599 \\
\hline Toulouse & $43^{\circ} 31^{\prime} \mathrm{N}, 01^{\circ} 28^{\prime} \mathrm{E}$ & 2002 & loamy-calcareous & 175 & Pea & $60-180$ & 11.85 & 3607 & 431 \\
\hline
\end{tabular}

Hoogenboom and White, 2003; Houles et al., 2004). This approach is consistent with the main objective of researchers; that is to find the model that fits reality the best. Conversely, the use of models as decision-making tools does not necessarily require a high predictive quality. An observed fit of medium quality could be compatible with a good decision quality as, for example, when ranking nitrogen strategies (David et al., 2004, 2005) or segregating wheat batches according to protein concentration predictions (Le Bail and Makowski, 2004). Thus, it is essential to test the ability of the model to improve the decision as compared with the decision that would be taken without the model, and not only to quantify its predictive quality.

Because of a relatively small number of genotypic parameters and inputs and their easy measurement in field conditions, the Azodyn model was chosen as a cultivar evaluation tool. It is hoped that the model could be developed for cultivar evaluation for different cultivar users, such as breeders, producers or technical institutes. The model simulates the grain yield and grain protein content of a wheat crop given the availability of soil nitrogen, weather data and cultivar characters. The predictive quality of the model has already been estimated for a wide range of environments in agricultural conditions (David et al., 2004; Jeuffroy and Recous, 1999; Jeuffroy et al., 2000) and for various cultivars (Barbottin, 2004). The objective of our research was to evaluate the ability of this model (a) to rank cul-

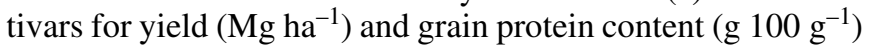
for diverse environments and (b) to identify the best adapted cultivar(s) for each nitrogen management condition simulated compared with the cultivar growers' predictive statistics.

\section{MATERIALS AND METHODS}

\subsection{Wheat crop model Azodyn}

The Azodyn wheat crop model has already been described in previous papers (David et al., 2004, 2005; Jeuffroy and Recous, 1999). It predicts the consequences of fertilizer man- agement on crop yield, grain protein content and mineral $\mathrm{N}$ in the soil at harvest on a daily time step, taking into account soil characteristics, weather conditions and cultivar characteristics (Barbottin, 2004). It simulates the effects of nitrogen stress and water deficiency on the availability of soil nitrogen, plant growth, crop nitrogen uptake and finally, grain yield and nitrogen content.

The model requires few input data that are easily measured in farmers' fields: soil characteristics from a classical soil analysis (\%clay, $\% \mathrm{CaCO}_{3}$ and \%organic soil $\mathrm{N}$ ), daily weather data from the nearest weather station (mean temperature, total radiation and rainfall) and crop above-ground biomass at the end of winter. It requires developmental stages, varying among genotypes (e.g. the date of the beginning of stem elongation and flowering). Cultivar differences are also taken into account using three genotypic parameters of the plant sub-model: the maximum yield (Ymax), the maximum grain number that can be elaborated according to radiation interception (GNmax) and the maximum thousand-grain weight (TGWmax).

\subsection{Site specifications and cultivar measurement}

The model was evaluated on experimental data drawn from fertilization experiments carried out in several sites in the major wheat-growing areas of France, during two years (2000-01 and 2001-02). A description of the main characteristics of these experiments is given in Table I, and more details were given by Barbottin et al. (2005). The availability of soil $\mathrm{N}$ varied greatly among sites because of (i) the various amounts of mineral $\mathrm{N}$ measured at the end of winter (from $30 \mathrm{~kg} \mathrm{ha}^{-1}$ in Lille to $175 \mathrm{~kg} \mathrm{ha}^{-1}$ in Toulouse), (ii) the nature of the preceding crops, leading to various amounts of mineral $\mathrm{N}$ from residue mineralization during the cycle and (iii) the various $\mathrm{N}$ fertilizer applications (high and low N levels) (Tab. I). Two N treatments (high and low supply) were applied at each location and in each year, except at the Lille experimental station. The high $N$ level was calculated as the amount of $\mathrm{N}$ necessary to reach the potential 
Table II. Cultivar earliness (heading scores from $1=$ very late to $9=$ very early) and parameter values for the Azodyn model (Ymax $=$ maximum yield, TGWmax = maximum thousand-grain weight and GNmax = potential number of grains per meter square per intercepted radiation unit). Cultivar parameter values were estimated using an independent data set.

\begin{tabular}{lcccc}
\hline Genotype & Earliness & \multicolumn{3}{c}{ Cultivar parameter values } \\
\cline { 2 - 5 } & Heading score & Ymax & TGWmax & Grains m $^{-2} \mathrm{MJ}^{-1}$ \\
\hline Arche & Unit less & Mg ha & g & 13.8 \\
Baltimor & 6 & 11.4 & 44.7 & 14.0 \\
Camp-Rémy & 6 & 11.1 & 44.0 & 13.3 \\
DI9714 & 5 & 10.7 & 44.9 & 12.0 \\
Galibier & not available & 10.9 & 51.0 & 9.2 \\
Hynoprécia & 8 & 8.6 & 46.6 & 11.9 \\
Isengrain & 6.5 & 11.2 & 52.3 & 13.5 \\
Oratorio & 7 & 11.3 & 49.6 & 13.9 \\
Ornicar & 6.5 & 11.2 & 43.7 & 15.6 \\
Récital & 6.5 & 11.1 & 43.7 & 14.0 \\
Renan & 8 & 10.8 & 44.1 & 9.0 \\
Rumba & 6 & 9.6 & 53.9 & 12.0 \\
Soissons & 5.5 & 11.0 & 50.2 & 13.9 \\
Trémie & 7 & 10.8 & 45.3 & 12.0 \\
\hline
\end{tabular}

yield of the experimental site, using the balance-sheet method (Rémy and Hébert, 1977). The low N supply level was defined as the high $\mathrm{N}$ level minus one hundred units of $\mathrm{N}$.

Weather conditions throughout the crop cycle were variable among sites and years (Tab. I). Thus, 21 environmental conditions were defined, varying in year, site and $\mathrm{N}$ fertilization level. These environmental conditions differ in terms of mean temperature $\left({ }^{\circ} \mathrm{C}\right)$, cumulative rainfall $(\mathrm{mm})$ and cumulative solar radiation $\left(\mathrm{MJ} \mathrm{m}^{-2}\right)$ during the whole crop cycle, and were characterized by several limiting factors that occurred and limited yield in comparison with the target (Barbottin et al., 2005). According to the identified limiting factors, two groups of environments could be defined: environments without limiting factors except nitrogen, and environments with multiple limiting factors such as severe drought, lodging and foliar diseases, which are not taken into account in the model.

Ten cultivars were used in the first year, and fourteen in the second year of these experiments. Cultivars differed in earliness and yielding level, representing the range of French commercial cultivars (Tab. II). They were sown in three replicates in each of the 21 environments according to the regional sowing date recommendations. In each case, the model inputs were determined, and the yield and grain protein content of each genotype were measured at harvest.

At the end of winter and at harvest, one plot per replicate $(1 \mathrm{~m}$ on two consecutive sowing rows) was sampled for each environment. Samples were separated into vegetative (leaf and culm) and reproductive parts. Ears were separated into grains and chaff. Yield was determined by weighing grain samples after oven-drying for $72 \mathrm{~h}$ at $80^{\circ} \mathrm{C}$. Grains were then ground in a mill to generate $1-\mathrm{mm}$ particles and the nitrogen content of grains was analyzed using a Carlo-Erba NA 1500 CN Analyzer (Fisons Instrument - Thermoelectron). Ten-milligram samples were analyzed using the Dumas method consisting of the combustion of the sample, separation of the different components $\left(\mathrm{N}_{2}, \mathrm{H}_{2} \mathrm{O}, \mathrm{CO}_{2}, \mathrm{O}_{2}\right)$ and quantification of the $\mathrm{N}_{2}$ content.

\subsection{Model evaluation procedure}

The ability of the Azodyn model to predict the genotype ranking and the best-adapted genotype(s) is called "decisional quality". It is generally assumed that breeders expect to identify cultivars with high and stable yield and grain protein content across a wide range of environments. Their choices are generally based on mean performance values and variance around these means. For their part, technical advisors expect to identify the best cultivars to be used for the regional soil/climatic and crop management conditions. Lastly, farmers expect to use the best cultivar for their specific growing conditions. We compared the decisional quality of the model with that of the statistics generally used by breeders, technical advisors and farmers to choose cultivars.

\subsection{Identifying the best cultivar}

The model was run over the 246 combinations of cultivar $\times$ environment and the mean yield, mean grain protein content and the environmental variance were estimated for each cultivar. The environmental variance was estimated as proposed by Becker and Leon (1988) as:

$$
\mathrm{S}^{2}=\sum_{\mathrm{i}=\mathrm{n}}^{\mathrm{N}}(\mathrm{Ygi}-\mathrm{Yg})^{2} /(\mathrm{N}-1)
$$


Table III. Observed and simulated mean yield, grain protein content (GPC) and associated variances ( $\left.\mathrm{S}^{2}\right)$ for each cultivar in all the environments and in the environments without limiting factors except $\mathrm{N}$ (values in brackets). Values followed by the same letter are not significantly different at the 0.05 probability level.

\begin{tabular}{lcccccccc}
\hline Cultivar & Obs. yield & Sim. yield & $\begin{array}{c}\text { Obs. S } \text { for } \\
\text { yield }\end{array}$ & $\begin{array}{c}\text { Sim. } S^{2} \\
\text { for yield }\end{array}$ & Obs. GPC & Sim. GPC & $\begin{array}{c}\text { Obs. S } \\
\text { for GPC }\end{array}$ & $\begin{array}{c}\text { Sim. S } \\
\text { for GPC }\end{array}$ \\
\hline Arche & $8.1^{\mathrm{a}}(9.8)$ & $9.3^{\mathrm{a}}(9.7)$ & $3.2(1.2)$ & $1.7(0.7)$ & $10.6^{\mathrm{def}}(10.4)$ & $9.2^{\mathrm{c}}(9.8)$ & $1.4(1.0)$ & $1.8(1.8)$ \\
Baltimor & $8.1^{\mathrm{a}}(10.1)$ & $9.1^{\mathrm{a}}(8.9)$ & $4.0(2.1)$ & $1.1(0.8)$ & $10.5^{\mathrm{def}}(10.0)$ & $9.9^{\mathrm{c}}(10.8)$ & $3.1(1.7)$ & $2.3(1.1)$ \\
Camp-Rémy & $7.0^{\mathrm{bc}}(8.6)$ & $9.1^{\mathrm{a}}(9.3)$ & $3.0(2.9)$ & $1.6(0.6)$ & $11.6^{\mathrm{c}}(11.2)$ & $9.4^{\mathrm{c}}(9.7)$ & $1.7(1.3)$ & $1.6(1.7)$ \\
DI9714 & $7.8^{\mathrm{ab}}(9.5)$ & $9.2^{\mathrm{a}}(9.3)$ & $2.3(1.2)$ & $1.7(0.6)$ & $11.2^{\mathrm{cd}}(10.9)$ & $9.2^{\mathrm{c}}(9.9)$ & $1.4(0.9)$ & $1.8(1.7)$ \\
Galibier & $5.9^{\mathrm{d}}(6.9)$ & $7.2^{\mathrm{c}}(7.3)$ & $1.9(2.3)$ & $1.0(0.8)$ & $14.0^{\mathrm{a}}(14.0)$ & $12.0^{\mathrm{a}}(14.2)$ & $2.5(2.3)$ & $7.3(1.1)$ \\
Hynoprécia & $8.2^{\mathrm{a}}(10.2)$ & $9.4^{\mathrm{a}}(9.7)$ & $3.4(1.4)$ & $1.4(0.7)$ & $10.9(10.6)$ & $9.1^{\mathrm{c}}(9.8)$ & $1.1(1.1)$ & $1.9(1.7)$ \\
Isengrain & $8.1(9.9)$ & $9.4^{\mathrm{a}}(9.6)$ & $3.3(1.4)$ & $1.2(0.8)$ & $10.5^{\mathrm{def}}(10.3)$ & $8.9^{\mathrm{c}}(9.8)$ & $1.2(1.1)$ & $1.9(1.8)$ \\
Oratorio & $8.0^{\mathrm{ab}}(9.4)$ & $9.1^{\mathrm{a}}(9.5)$ & $2.8(1.9)$ & $1.2(0.7)$ & $11.0^{\text {cde }}(10.7)$ & $9.6^{\mathrm{c}}(10.5)$ & $1.5(1.6)$ & $2.6(1.9)$ \\
Ornicar & $7.9^{\mathrm{a}}(9.4)$ & $9.2^{\mathrm{a}}(9.2)$ & $2.8(2.0)$ & $1.5(1.5)$ & $11.0^{\text {cde }}(10.9)$ & $9.0^{\mathrm{c}}(9.9)$ & $1.7(1.4)$ & $1.9(1.8)$ \\
Récital & $7.0^{\mathrm{bc}}(8.6)$ & $8.9^{\mathrm{a}}(9.3)$ & $2.9(1.4)$ & $1.5(1.1)$ & $10.9^{\text {cde }}(10.7)$ & $8.8^{\mathrm{c}}(9.8)$ & $1.0(1.1)$ & $2.2(2.2)$ \\
Renan & $6.8^{\mathrm{c}}(8.1)$ & $8.0^{\mathrm{b}}(8.5)$ & $1.8(0.7)$ & $1.9(0.8)$ & $12.4^{\mathrm{b}}(12.2)$ & $10.7^{\mathrm{b}}(11.1)$ & $1.7(1.3)$ & $2.2(2.0)$ \\
Rumba & $7.9^{\mathrm{ab}}(9.6)$ & $9.2^{\mathrm{a}}(9.5)$ & $3.2(1.7)$ & $1.4(0.6)$ & $11.0^{\text {cde }}(10.6)$ & $9.1^{\mathrm{c}}(9.6)$ & $1.5(0.8)$ & $1.8(1.9)$ \\
Soissons & $7.4^{\mathrm{abc}}(9.0)$ & $9.1^{\mathrm{a}}(9.4)$ & $2.5(1.0)$ & $1.2(0.8)$ & $11.1^{\text {cde }}(11.0)$ & $8.9^{\mathrm{c}}(9.8)$ & $1.2(1.6)$ & $2.0(1.9)$ \\
Trémie & $8.3^{\mathrm{a}}(10.2)$ & $9.4^{\mathrm{a}}(9.7)$ & $5.0(4.4)$ & $2.1(2.8)$ & $10.2^{\mathrm{f}}(10.2)$ & $9.4^{\mathrm{c}}(10.5)$ & $2.1(2.8)$ & $2.7(1.3)$ \\
\hline
\end{tabular}

where $\mathrm{N}$ is the number of observations for each cultivar, Ygi represents the observed variable $\mathrm{Y}$ for the cultivar $\mathrm{g}$ in environment $\mathrm{i}$, and $\mathrm{Yg}$ is the mean value of variable $\mathrm{Y}$ for cultivar $\mathrm{g}$. In order to evaluate the ability of the model to identify significant cultivar groups, we performed a variance analysis on observed and simulated yields and grain protein content using the SAS PROC GLM procedure (SAS Institute, 1990). Significant differences in cultivars for mean yield and grain protein content were identified using the Newman \& Keuls test $(\alpha=$ $0.05)$.

\subsection{Selecting the best cultivar to be chosen in each environment tested}

Cultivars were ranked in each environment, considering their observed and simulated yield and grain protein content. Two cultivars were considered as belonging to two different classes when they differed by more than $0.6 \mathrm{Mg} \mathrm{ha}^{-1}$ for yield

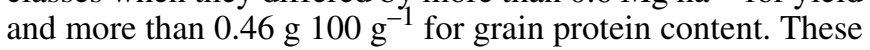
thresholds represent the mean significant differences for yield and grain protein content observed between cultivars, using the test with a least square difference (LSD) below 0.05. As proposed by David et al. (2004), observed and simulated rankings were compared using the Spearman ranking order test in the different environments. Ranking error was estimated as the difference between observed and simulated ranking.

\subsection{Comparison with the most widely-used statistics to predict performance of genotypes}

We compared the predictions of the Azodyn crop model with the predictions made using the average yield and grain protein content as an estimator of the cultivars' performance in each environment. The mean squared error of prediction (MSEP) of the Azodyn model was compared with the mean squared error of prediction of the average model of each cultivar. The effi- ciency of the Azodyn model was estimated as the ratio between the MSEP of the Azodyn model and the MSEP of the average:

$$
\mathrm{EF}=\frac{\sum_{\mathrm{N}} 1 / \mathrm{N}(\mathrm{Ygi}-\mathrm{f}(\mathrm{xi}, \beta \mathrm{g}))^{2}}{\sum_{\mathrm{N}} 1 / \mathrm{N}\left(\mathrm{Ygi}-\overline{\mathrm{Y}}_{(-\mathrm{i})}\right)^{2}}
$$

where Ygi is the observed variable $\mathrm{Y}$ for the cultivar $\mathrm{g}$ in environment $\mathrm{i}, \mathrm{f}(\mathrm{xi}, \beta \mathrm{g})$ is the predicted value of the variable $\mathrm{Y}$ using the Azodyn model using the input of case $i$ and the cultivar parameters $\beta g$, and $\bar{Y}_{(-i)}$ represents the mean observed variable $\mathrm{Y}$ value estimated in the $\mathrm{N}-\mathrm{i}$ environments. When the efficiency ratio (EF) is lower than 1, the MSEP of the genotypic model is less than the MSEP of the average, which means that it is preferable to use the model for cultivar choice instead of the average observed in a range of environments.

\section{RESULTS AND DISCUSSION}

The model was run over the 246 combinations of cultivar $\times$ environment. We estimated the ability of the model: to account for the average performances of the cultivars, to rank these cultivars in each of the environments tested, and to be a better predictive tool than the average yield and the grain protein content.

\subsection{Cultivar performance and stability}

For the 21 environments tested, the model overestimated the mean yield values and underestimated the grain protein values for all genotypes (Tab. III). The root mean square error of the model (RMSEP) was rather good for yield, and for grain protein content (RMSEP yield $=1.4 \mathrm{Mg} \mathrm{ha}^{-1}$, RMSEP grain protein

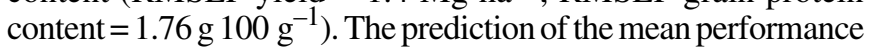
for each genotype was greatly improved when environments 
with severe drought, lodging or diseases were excluded (Tab. III). The root mean squared error of prediction for yield decreased from 1.4 to $0.5 \mathrm{Mg} \mathrm{ha}^{-1}$ and from 1.76 to $0.88 \mathrm{~g}$ $100 \mathrm{~g}^{-1}$ for grain protein content. Nevertheless, it was possible to reproduce significant differences in the yield and grain protein content between cultivars. According to the Student-Newman-Keuls test $(\alpha=0.05)$, the model was able to identify the two genotypes (Renan and Galibier) that differed significantly from the others for yield and grain protein content.

Observed and simulated variances are presented in Table III. In all cases the model underestimated yield variation ( simulated $\mathrm{S}^{2}$ values from 1.0 to $2.1 \mathrm{Mg}^{2} \mathrm{ha}^{-2}$, observed $\mathrm{S}^{2}$ values from 1.8 to $5.0 \mathrm{Mg}^{2} \mathrm{ha}^{-2}$ ). Because of the limiting factors that were not taken into account by the model, such as foliar disease, lodging and severe drought, the model was not able to reproduce yield losses due to these factors. Prediction of the environmental variance was not improved when only the environments without severe drought, lodging or diseases were considered (simulated $S^{2}$ values from 0.6 to $1.5 \mathrm{Mg}^{2} \mathrm{ha}^{-2}$, observed $\mathrm{S}^{2}$ values from 0.7 to $4.4 \mathrm{Mg}^{2} \mathrm{ha}^{-2}$ ). Compared with yield, variations in grain protein content around the mean value seemed better simulated (simulated $\mathrm{S}^{2}$ values from 1.6 to $7.3 \mathrm{~g}^{2}$ $100 \mathrm{~g}^{-2}$, observed $\mathrm{S}^{2}$ values from 1.0 to $3.1 \mathrm{~g}^{2} 100 \mathrm{~g}^{-2}$ ) by the model and it was possible to identify the three most variable cultivars, i.e. with the highest $S^{2}$ values, within the fourteen tested for the grain protein: Baltimor, Galibier and Trémie (Tab. III).

These first results showed that it was possible to reproduce cultivar effects on yield and grain protein content and to identify the highest-yielding genotype to be used in a wide range of environments, using the Azodyn crop model with a small number of cultivar parameters (at least five cultivar traits). The results show that mean yield and grain protein content were rather well estimated when a large number of different types of environment were considered and were further improved when considering environments varying in nitrogen availability (Tab. III). Grain protein content predictions were not at all satisfactory when all environments were considered. Yet, in the most frequent situations of farmers' fields in the north of France (without severe disease and drought), the predictive quality was

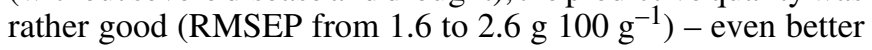
than some previous models (Asseng et al., 2002b; Brisson et al., 2003). Simulation errors reported by our and other studies on grain protein content show that good accuracy is rather difficult to achieve (Houles et al., 2004; Meinke et al., 1998). Because of the high sensitivity of nitrogen transfers into the grain to weather factors (Smith and Gooding, 1999), it will probably be difficult for crop models to reach lower prediction errors for this variable. However, the increase in predictive quality for yield and grain protein content did not appear to be essential, as good decisions as to the choice of genotype can already be made with the model.

\subsection{Ranking order: identification of the best genotype for each environment}

Because of the great genotype by environment interaction effect on yield and grain protein content, cultivar growers generally prefer to choose the genotypes that will give the best results in their own conditions. Cultivars were ranked accord- ing to their observed and simulated yield and grain protein content. The results of the Spearman comparison test performed between observed and simulated ranking order in the different environments are presented in Table IV.

The ranking ability of the model for yield was better than for grain protein content. In 10 environments out of 21 for yield but only 6 environments out of 21 for grain protein content, the simulated ranking was satisfactorily close to the observed one (Spearman coefficient 0.50 ). In more than $80 \%$ of cases for yield and $77 \%$ of cases for grain protein content, the ranking error was of one rank or less (Fig. 1a). In $61 \%$ of cases for yield and $75 \%$ of cases for grain protein content, the model was able to identify the best cultivars to use (corresponding to the first rank) to reach the highest yield or grain protein content. When the ranking order was not consistent with the observed one, the model tended to underestimate (by one class) the number of classes in comparison with the observed number of classes (Tabs. V, VI). Thus, ranking differences between observed and simulated data mainly concerned Isengrain, Récital, Soissons and Trémie, for which the model overestimated the yield (Tabs. V, VI).

Comparison between observed and simulated ranking for yield and grain protein content showed that the model was able to rank most genotypes with one or less ranking error, independently of the limiting factors considered. In each environment considered, the model was able to identify the best genotype to use in order to reach the highest grain protein content and yield. Similar results were obtained by Mavromatis et al. (2001) for a soybean crop model. Most of the ranking errors were explained by cultivars for which yield and grain protein content differences were not explained by the cultivar parameters used in the Azodyn model.

These first results on model accuracy for cultivar-specific adaptation to environmental factors, as defined by Gallais (1992), may support using this type of crop model as a decisionmaking tool for genotypic management over various nitrogen and weather constraints, helping to identify the best genotype to be used in each case. Nevertheless, since the response of genotypes to diseases and water stress varies, there should be some value in identifying the genotypes adapted to give the best gross margin, even in low input crop management. To this end, as the number of limiting factors is high and their period of occurrence is variable, static agronomic models such as that proposed by Loyce et al. (2002) could be more easily usable.

\subsection{Predictive quality of the Azodyn crop model in comparison with the most frequently used statistics}

The efficiency of the Azodyn model was tested against the statistics normally used to predict wheat yield and grain protein content in various environments, i.e. average yield and grain protein content (Tab. VII). When evaluated for all environments, the Azodyn crop model did not appear to be better at simulating genotype yield or grain protein content in different situations than the average yield and grain protein content. In eight cases out of fourteen, for yield, the prediction error of the model was close to that of the average yield (model efficiency from 0.9 to 1.3 ). When considering the environments without severe drought, disease and lodging, i.e. the common conditions 
Table IV. Values of the Spearman ranking order test between observed and simulated cultivars ranking for yield and grain protein content (GPC). Statistical significance is indicated near the coefficient values $(*, * * * * *$ significant at $P \leq 0.10,0.05$ and 0.01 , respectively, ns $=$ not significant).

\begin{tabular}{|c|c|c|c|c|}
\hline Site & Year & $\mathrm{N}$ level & $\begin{array}{l}\text { Spearman correlation coefficient for } \\
\text { yield }\end{array}$ & $\begin{array}{c}\text { Spearman correlation coefficient } \\
\text { for GPC }\end{array}$ \\
\hline Clermont-F & 2001 & High N level & $0.59 * *$ & $0.03 \mathrm{~ns}$ \\
\hline Clermont-F & 2001 & Low $\mathrm{N}$ level & $0.69 * * *$ & $0.04 \mathrm{~ns}$ \\
\hline Clermont-F & 2002 & High N level & $0.35 \mathrm{~ns}$ & $0.65^{* *}$ \\
\hline Clermont-F & 2002 & Low $\mathrm{N}$ level & $0.55 * * *$ & $0.39 \mathrm{~ns}$ \\
\hline Dijon & 2001 & High $N$ level & $0.34 \mathrm{~ns}$ & $0.24 \mathrm{~ns}$ \\
\hline Dijon & 2001 & Low $\mathrm{N}$ level & $0.08 \mathrm{~ns}$ & $0.81 * * *$ \\
\hline Le Moulon & 2001 & High $\mathrm{N}$ level & $0.00 \mathrm{~ns}$ & $0.27 \mathrm{~ns}$ \\
\hline Le Moulon & 2001 & Low N level & $0.66^{* * *}$ & $0.03 \mathrm{~ns}$ \\
\hline Le Moulon & 2002 & High $N$ level & $0.24 \mathrm{~ns}$ & $0,42 \mathrm{~ns}$ \\
\hline Le Moulon & 2002 & Low N level & $0.15 \mathrm{~ns}$ & $0.45 \mathrm{~ns}$ \\
\hline Lille & 2002 & High N level & $0.47 * *$ & $0.22 \mathrm{~ns}$ \\
\hline Mons & 2001 & High $N$ level & $0.64 * * *$ & $0.55^{*}$ \\
\hline Mons & 2001 & Low N level & $0.65^{* * *}$ & $0.58 *$ \\
\hline Rennes & 2001 & High N level & $0.07 \mathrm{~ns}$ & $0.13 \mathrm{~ns}$ \\
\hline Rennes & 2001 & Low N level & $0.25 \mathrm{~ns}$ & $0.28 \mathrm{~ns}$ \\
\hline Rennes & 2002 & High $N$ level & $0.51 * *$ & $0.52 *$ \\
\hline Rennes & 2002 & Low N level & $0.64 * * *$ & $0.18 \mathrm{~ns}$ \\
\hline Toulouse & 2001 & High $N$ level & $0.85 * * *$ & $0.53 \mathrm{~ns}$ \\
\hline Toulouse & 2001 & Low N level & $0.03 \mathrm{~ns}$ & $0.15 \mathrm{~ns}$ \\
\hline Toulouse & 2002 & High N level & $0.17 \mathrm{~ns}$ & $0.37 \mathrm{~ns}$ \\
\hline Toulouse & 2002 & Low $\mathrm{N}$ level & $0.69 * * *$ & $0.59 * *$ \\
\hline
\end{tabular}

Table V. Percentage of cases for each genotype with differences between observed and simulated ranking (Drank) of 0, 1, 2, 3, 4 and 5 ranks for yield.

\begin{tabular}{|c|c|c|c|c|c|c|}
\hline Cultivar & Drank $=0$ & Drank $=1$ & Drank $=2$ & Drank $=3$ & Drank $=4$ & Drank $=5$ \\
\hline Arche & 29 & 33 & 29 & & & 0 \\
\hline Baltimor & 11 & 33 & 44 & 0 & 11 & \\
\hline Camp-Rémy & 43 & 52 & 5 & & & \\
\hline DI9714 & 29 & 62 & 5 & 5 & & \\
\hline Galibier & 67 & 22 & 0 & 11 & & \\
\hline Hynoprécia & 10 & 67 & 14 & & & \\
\hline Isengrain & 19 & 38 & 29 & 5 & 5 & \\
\hline Oratorio & 33 & 67 & & & & \\
\hline Ornicar & 33 & 67 & & & & \\
\hline Récital & 14 & 52 & 24 & 5 & 0 & 5 \\
\hline Renan & 76 & 24 & & & & \\
\hline Rumba & 29 & 67 & 5 & & & \\
\hline Soissons & 29 & 43 & 19 & 10 & & \\
\hline Trémie & 33 & 44 & 11 & 11 & & \\
\hline
\end{tabular}


Table VI. Percentage of cases for each genotype with differences between observed and simulated ranking (Drank) of 0, 1, 2, 3, 4 and 5 ranks for the grain protein content.

\begin{tabular}{|c|c|c|c|c|c|c|}
\hline Cultivar & Drank $=0$ & Drank $=1$ & Drank $=2$ & Drank $=3$ & Drank $=4$ & Drank $=5$ \\
\hline Arche & 38 & 24 & 38 & & & \\
\hline Baltimor & 11 & 22 & 56 & 11 & & \\
\hline Camp-Rémy & 43 & 52 & 5 & & & \\
\hline DI9714 & 33 & 52 & 14 & & & \\
\hline Galibier & 78 & 0 & 11 & 11 & & \\
\hline Hynoprécia & 19 & 62 & 19 & & & \\
\hline Isengrain & 24 & 33 & 33 & 10 & & \\
\hline Oratorio & 33 & 67 & & & & \\
\hline Ornicar & 44 & 53 & & & & \\
\hline Récital & 14 & 48 & 29 & 10 & & \\
\hline Renan & 81 & 19 & & & & \\
\hline Rumba & 29 & 57 & 14 & & & \\
\hline Soissons & 29 & 29 & 43 & & & \\
\hline Trémie & 33 & 33 & 22 & 11 & & \\
\hline
\end{tabular}
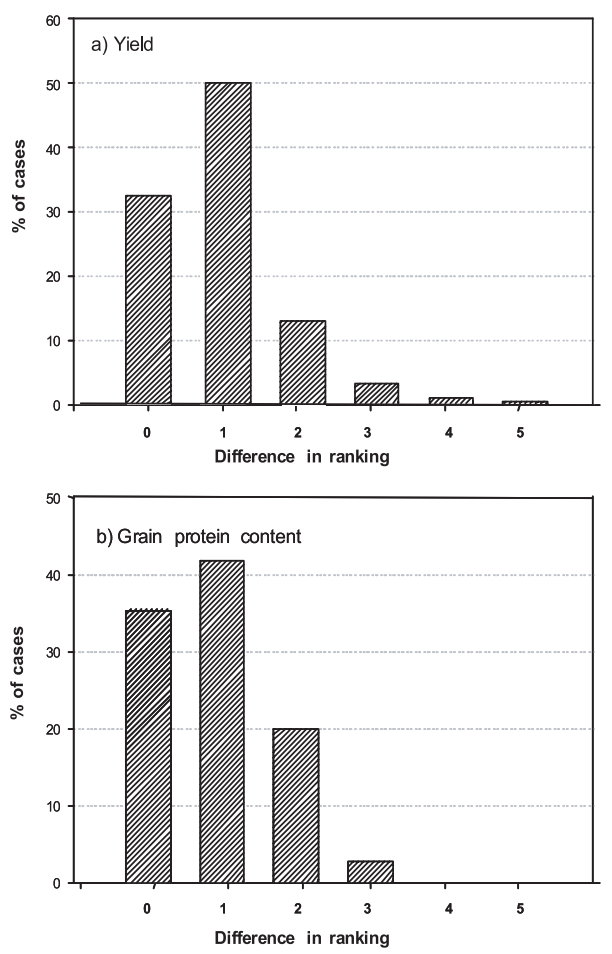

Figure 1. Percentage of cases, out of 246 combinations of cultivar by environment, with differences in ranking between observed and simulated ranking, of 0, 1, 2, 3, 4 and 5 ranks, for yield (a) and grain protein content (b). Ranking order was estimated using observed and simulated yield and grain protein content.

of winter wheat in France, the model's efficiency was rather high. The efficiency ratio varied from 0.5 to 1.3 (Tab. VII). Thus, the Azodyn model appeared to be a better tool for predicting the yield of all cultivars than the average yield. In all cases, the efficiency of the model for grain protein prediction was low. The efficiency ratio varied from 1.2 to 6.2 in all environments and from 1.0 to 2.4 for the environments without severe drought, disease and lodging.

We evaluated the ability of the model to give a better prediction than the average yield and grain protein content generally used by cultivar growers to predict cultivar performances. This evaluation step is rarely done in the literature for a model used as a decision-making tool. The results obtained for yield show that the crop model has the same predictive quality as the average yield when run for a wide range of environments and was more accurate when used on the main wheat-growing environments in France.

These results obtained for a user-oriented model, using a small number of cultivar parameters to reproduce cultivar by environment interaction, show that it is pertinent for cultivar growers to use the Azodyn crop model as a decision tool. The parameters used in this study were estimated on an independent data set and are easily measurable during registration or breeding trials. Indeed, this calibration step has been shown to be one of the constraints identified for models to be used routinely for crop management (Meinke et al., 1998).

\section{CONCLUSION}

The rapid turnover of winter wheat cultivars in France eliminates the possibility that cultivar growers can carry out experiments to evaluate any new cultivar in a large range of environments. Our results have shown that the user-oriented wheat model Azodyn sufficiently reproduced cultivars' mean yield and grain protein content for a wide range of environments, using only five cultivar traits in the model. The simulated ranking of genotypes in the 21 environments tested show that this crop model is a useful tool for evaluating a genotype 
Table VII. Efficiency (EF) of the model at predicting the performance of the 14 genotypes tested in all environments (a) and in the environments without severe drought, disease or lodging (b). Efficiency was estimated as the ratio between the mean squared error of prediction of the Azodyn model and the mean squared error of the average yield or grain protein content (GPC) for each genotype.

\begin{tabular}{lcccc}
\hline Cultivar & EF for yield (a) & EF for GPC (a) & EF for yield (b) & EF for GPC (b) \\
\hline Arche & 1.1 & 2.6 & 0.5 & 1.1 \\
Baltimor & 1.3 & 1.2 & 0.5 & 1.4 \\
Camp-Rémy & 2.1 & 4.1 & 0.8 & 2.3 \\
DI9714 & 1.7 & 4.8 & 0.2 & 2.1 \\
Galibier & 2.4 & 3.0 & 0.7 & 1.1 \\
Hynoprécia & 1.0 & 4.4 & 0.6 & 1.3 \\
Isengrain & 0.9 & 3.3 & 0.6 & 1.1 \\
Oratorio & 1.1 & 3.1 & 0.3 & 1.0 \\
Ornicar & 1.3 & 2.7 & 1.3 & 1.4 \\
Récital & 1.9 & 6.2 & 1.0 & 1.4 \\
Renan & 1.4 & 3.1 & 0.7 & 1.5 \\
Rumba & 1.1 & 4.0 & 0.8 & 1.4 \\
Soissons & 1.6 & 5.3 & 0.6 & 1.4 \\
Trémie & 1.3 & 3.1 & & \\
\hline
\end{tabular}

within a group of genotypes, always identifying the best genotype as regards yield or the best grain protein content. Moreover, when considering the main production conditions, the model was shown to be a better tool for yield and grain protein content prediction than the average generally used by cultivar growers. Thus crop models may be used as tools to help breeding programs and technical advisors, identifying cultivar characters to be selected or cultivars to be used in specific environments.

Acknowledgements: We wish to thank P. Bérard (INRA ClermontFerrand), J. Troizier (INRA Grignon), S. Gilles and O. Gardet (INRA Le Moulon), M. Méosoone (SERASEM Lille), D. Béghin and D. Bouthor (INRA Mons), M. Trottet and J.Y. Morlais (INRA Rennes) and P. Bataillon (INRA Toulouse) and their collaborators for carrying out the experiments. We also thank F. Lafouge for sample analysis and B. Lefouillen, G. Grandeau, V. Tanneau and C. Souin for technical assistance. We are grateful to Semences de France, SERASEM, Florimond-Desprez and Arvalis - Institut du végétal for financial support.

\section{REFERENCES}

Agüera F., Villalobos F.J., Orgaz F. (1997) Evaluation of sunflower (Heliantus annuиs, L.) genotypes differing in early vigour using a simulation model, Eur. J. Agron. 7, 109-118.

Asseng S., Turner N.C., Ray J.D., Keating B.A. (2002a) A simulation analysis that predicts the influence of physiological traits on the potential yield of wheat, Eur. J. Agron. 17, 123-141.

Asseng S., Bar-Tal A., Bowden J.W., Keating B.A. Van Herwaarden A., Palta J.A., Huth H.I., Probert M.E. (2002b) Simulation of grain protein content with APSIM-Nwheat, Eur. J. Agron. 16, 25-42.

Asseng S., Turner N.C., Botwright T., Condon A.G. (2003) Evaluating the impact of a trait for increased specific leaf area on wheat yields using a crop simulation model, Agron. J. 95, 10-19.

Barbottin A. (2004) Utilisation d'un modèle de culture pour évaluer le comportement des génotypes: Pertinence de l'utilisation d'Azodyn pour analyser la variabilité du rendement et de la teneur en protéines du blé tendre, INA P-G, Paris, 188 p + annexes.

Barbottin A., Jeuffroy M.H., Lecomte C., Bouchard C. (2005) Genotype and environmental effects on nitrogen remobilization in wheat, Crop Sci. 45, 1141-1150.

Becker H.C., Leon J., Stability Analysis in Plant Breeding, Plant Breeding 101 (1988) 1-23.

Boote K.J., Jones J.W., Batchelor W.D., Nafziger E.D., Myers O. (2003) Genetic coefficients in the CROPGRO-Soybean model: links to field performance and genomics, Agron. J. 95, 32-51.

Brisson N., Gary C., Justes E., Roche R., Mary B., Ripoche D., Zimmer D., Sierra J., Bertuzzi P., Burger P., Bussière F., Cabidoche Y.M., Cellier P., Debaeke P., Gaudillère J.P., Hénault C., Maraux F., Seguin F., Sinoquet H. (2003) An overview of the crop model STICS, Eur. J. Agron. 18, 309-332.

Chapman S., Cooper M., Podlich D., Hammer G.L. (2003) Evaluating plant breeding strategies by simulating gene action and dryland environment effects, Agron. J. 95, 99-113.

Chatelin M.H., Aubry C., Poussin J.C., Meynard J.M., Massé J., Verjux N., Gate P., Le Bris X. (2005) DéciBlé, a software package for wheat crop management simulation, Agric. Syst. 83, 77-99.

Colson J., Bouniols A., Jones J.W. (1995) Soybean Reproductive Development: Adapting a model for european cultivars, Agron. J. 87, $1129-1139$

David C., Jeuffroy M.H., Recous S., Dorsainville F. (2004) Adaptation and assessment of the Azodyn model for managing the nitrogen fertilization of organic winter wheat, Eur. J. Agron. 21, 249-266.

David C., Jeuffroy M.H., Laurent F., Mangin M., Meynard J.M. (2005) The assessment of a decision-making tool for managing nitrogen fertilization of organic winter wheat, Eur. J. Agron. 23, 225-242.

Feyerherm A.M., Paulsen G.M., Fritz A.K. (2004) A statistical method for summarizing results of cultivar performance trials, Agron. J. 96, 992-996.

Gallais A. (1992) Adaptation et Adaptabilité en Amélioration des Plantes, Le Sélectionneur Français 42, 55-57. 
Hammer G.L., Vanderlip R.L. (1989) Genotype by Environment Interaction in Grain Sorghum. III. Modelling the impact in Field Environments, Crop Sci. 29, 385-391.

Hammer G.L., Muchow R.C. (1994) Assessing climatic risk to sorghum production in water-limited subtropical environments. I. Development and testing of a simulation model, Field Crops Res. 36, 221234.

Hoogenboom G., White J.W. (2003) Improving physiological assumption of simulation models by using gene-based approaches, Agron. J. 95, 82-89.

Houles V., Mary B., Guérif M., Makowski D., Justes E. (2004) Evaluation of the ability of the crop model STICS to recommended nitrogen fertilisation rates according to agro-environmental criteria, Agron. 24, 339-349.

Jeuffroy M.H., Recous S. (1999) Azodyn: a simple model simulating the date of nitrogen deficiency for decision support in wheat fertilization, Eur. J. Agron. 10, 129-144.

Jeuffroy M.H., Barré C., Bouchard C., Desmotes-Mainard S., DevienneBarret F., Girard M.L., Recous S. (2000) Fonctionnement d'un peuplement de blé en condition de nutrition azotée sub-optimale, in: Fonctionnement des peuplements végétaux sous contraintes environnementales, INRA, Paris.

Le Bail M., Makowski D. (2004) A model-based approach for optimizing segregation of soft wheat in country elevator, Eur. J. Agron. 21, 171-180.

Loyce C., Rellier J.P., Meynard J.M. (2002) Management planning for winter wheat with multiple objectives (2): ethanol-wheat production, Agric. Syst. 72, 33-57.
Mavromatis T., Boote K.J., Jones J.W., Irmak A., Shinde D., Hoogenboom G. (2001) Developing genetic coefficients for crop simulation models with data from crop performance trials, Crop Sci. 41, 40-51.

Meinke H., Hammer G.L., van Keulen H., Rabbinge R. (1997) Improving wheat simulation capabilities in Australia from a cropping systems perspective. III. The integrate wheat model (I_WHEAT), Agric. Syst. 8, 101-116.

Meinke H., Rabbinge R., Hammer G.L., van Keulen H., Jamieson P.D. (1998) Improving wheat simulation capabilities in Australia from a cropping systems perspective. II. Testing simulation capabilities of wheat growth, Eur. J. Agron. 8, 83-9.

Muchow R.C., Hammer G.L., Vanderlip R.L. (1994) Assessing climatic risk to sorghum production in water-limited subtropical environments. II. Effects of planting date, soil water at planting, and cultivar phenology, Field Crops Res. 36, 235-246.

Rémy J.C., Hébert J. (1977) Le devenir des engrais azotés dans le sol, C. R. Acad. Agric. France 63, 700-714.

Shorter R., Lawn R.J., Hammer G.L. (1991) Improving genotypic adaptation in crops - A role for breeders, physiologists and modellers, Exp. Agric. 27, 155-175.

Smith G.P., Gooding M.J. (1999) Models of wheat grain quality considering climate, cultivar and nitrogen effects, Agric. For. Meteorol. 94, 159-170.

Van Ittersum M.K., Leffelaar P.A., van Keulen H., Kropff M.J., Bastiaans L., Gourdriaan J. (2003) On approaches and applications of the Wageningen crop models, Eur. J. Agron. 18, 201-234.

Welch S.M., Jones J.W., Brennan M.W., Reeder G., Jacobson B.M. (2002) PC-Yield: model-based decision support for soybean production, Agric. Syst. 74, 79-98.
To access this journal online: www.edpsciences.org 